\title{
INTERNET TRADE AND THREAT OF THE GREY AREA
}

\author{
ANNA ĆWIAQAEA-MALYS*
}

\section{INTRODUCTION}

The grey area is a social and economic phenomenon which exists in countries with various types of economies. The range of this phenomenon may take different levels of intensity and forms. According to the methodology used by the Central Statistical Office, the grey area in Poland constituted $13 \%-14 \%$ of the economy. Central Statistical Office data show that the grey area is increasing, especially in the face of economic decline. The grey area negatively influences the whole economy as it causes a reduction in budget income, and thus inn the state budget. It has also a negative influence on economic competitiveness, placing entities from the grey area in a privileged position in relation to entities acting legally, especially in the sector of small and medium-sized enterprises ${ }^{1}$.

Estimates of the grey area in Poland for 2009 amount to $25.9 \%$ of GDP. The areas of the economy which are exposed to the grey area the most (according to $\mathrm{CSO}$ ) are as follows:

- building industry $(38.2 \%)$,

- wholesale trade and retail trade, car and motorcycle repairs, basic consumer goods and household goods (23.9\%),

- production $(22.9 \%)$,

- agriculture, hunting, forestry (14.3\%),

- households employing people (14.3\%),

- hotels and restaurants $(13.4 \%)^{2}$.

\section{GREY AREA VS. BLACK MARKET}

An element that distinguishes the grey area is unregistered employment. This follows from the fact that unregistered employment should be understood as wage labour performed without establishing an employment

DOI: $10.2478 /$ wrlae-2013-0019

* Assistant Professor, PhD, Eng., University of Wroclaw, Institute of Economic Sciences, Department of Finance Management, acwmalys@prawo.uni.wroc.pl

1 “Informacja o funkcjonowaniu ,szarej strefy” w polskiej gospodarce i przeciwdziałania jej przez służby skarbowe' < http://www.mf.gov.pl/dokument.php > 1, accessed 21.02.2012.

${ }^{2}$ F Schneider, 'The Shadow Economy in Europe (2011). Using electronic payment systems to combat the shadow economy', A.T. Kearney, Sponsored by VISA (2011), Shadow Economy (2011)[1].pdf, $17<\mathrm{http}$ ://www.visaeurope.com/idoc.ashx?docid=4d53b726-cd714ba5-a50b-735d11 ca4075\&version=-1> accessed 18.06.2012. 
relationship, as well as self-employed activities, and from which no taxes, social security contributions or financial commitments due to the state are paid $^{3}$. In contrast to legal and registered activity, the grey area activity can be characterized by ${ }^{4}$ :

- illigal economy, i.e. economic activities that violate legal provisions (e.g. narcotics, black currency market),

- unreported economy, i.e. income activities that are not registered with the tax office,

- unregistered economy, i.e. activities which are not registered in statistical institutions,

- non-formal economy, i.e. economic activities in which costs are avoided that result from regulations.

Illegal economy is colloquially described as the black market, and is identified with income from activities of a criminal nature. It is very often emphasized that there is an overlap between the grey area and black market because in many cases economic 'activity' in which people avoid paying taxes is directly connected with criminal activity ${ }^{5}$.

In statistical surveys, unregistered activity was defined in the following ways ${ }^{6}$ :

- wage labour performed without establishing an employment relationship, thus without a contract of employment, an order contract, contract for services or any other written contract between an employer and employee without regard to the type of ownership (also with reference to natural persons and individual agricultural undertakings); this work cannot be performed on the basis of appointment, nomination or choice; from unregistered work an employee does not receive any social insurance, and as a result the person is not entitled to social benefits; the period of this work is not taken into account as contributory from the point of view of the Social Insurance Institution; an employer does not remit to the Social Insurance Institution and Labour Fund the necessary sums resulting from wage disbursement; a tax is not paid on unregistered work income,

- work on your own account, if from the performed activity obligations due to the state are not met (e.g. taxes).

In this context, we may accept the following definition of the grey area as an area of an economic activity in which income gathered from activity not forbidden by the law is fully or partially hidden and the relevant state authorities are not informed of such. As a result, these actions contribute to the creation of GDP but are not directly registered (and at the same time they are neither counted nor registered). The phenomenon of the grey area is not

\footnotetext{
${ }^{3}$ Metodologia badań szarej strefy na rynku ustug turystycznych, pod kierownictwem Tadeusza Smugi, Instytut Koniunktur i Cen Handlu Zagranicznego (Warszawa 2005) 5.

4 ibid 6.

5 "Informacja o funkcjonowaniu ,szarej strefy” w polskiej gospodarce i przeciwdziałania jej przez służby skarbowe' < http://www.mf.gov.pl/dokument.php > 1, accessed 21.02.2012. ${ }^{5}$ Schneider (n 2) 17-20.

${ }^{6}$ Praca nierejestrowana $w$ Polsce $w 2010$ r... Informacje i opracowania statystyczne, Główny Urząd Statystyczny (Warszawa 2011) 10.
} 
officially subject to reporting although it influences to a great extent the GDP and economic development of every country. Due to this fact it is necessary to measure this phenomenon, and to evaluate its scope and structure but also the dynamics of changes ${ }^{7}$. In practice, measurement of this phenomenon amounts to an estimation of lost income to the state budget. The results of estimating the scope of the grey area with the use of chosen methods - apart from differences - show that the dynamics of the grey area indicate constant growth $^{8}$.

\section{THE RANGE OF THE GREY AREA}

Reasons for the existence of the grey area which are mentioned in the literature can be placed or identified in the following primary areas of economic and social life:

1. in the area of legal regulations standardizing economic activity, where we can include: an ambiguous and inconsistent system of legal regulations, fiscal stringency (excessive tax burden), a developed system of reliefs and preferences, diversity and multitude of tax rates (in the case of VAT and excise tax) for similar groups of goods;

2 . in the area of regulations of the general insurance scheme; here we can cite an unclear and overly-complicated system of obligations placed on employers;

3. in the area of labour law, where we can cite: inflexible labour law regulations (including requirements according to workplace safety and hygiene, rules of employing and dismissing employees, in particular requirements for employers that employ foreigners);

4. low awareness of society regarding illegally-taken measures with reference to economic activity, i.e. that there is a belief about the low risk of irregularities being discovered and low awareness of illegal employment ${ }^{9}$;

5. in the institutional environment, where we can point out honesty, efficiency and competence of the workers of public sector, which is responsible for detecting the appearance of legality of those who are dishonest participants in market activities ${ }^{10}$.

According to some sources, the grey area develops in a so-called overregulated economy, especially when ${ }^{11}$ :

- a country has too-weak monitoring instruments and incoherent legislation,

- there exists traditions of violating rights and low standards of administrative authorities,

- there is weak promotion of ethical attitudes, legal entrepreneurship, social solidarity.

\footnotetext{
${ }^{7}$ Metodologia badań szarej strefy na rynku ustug (n 3) 49.

8 ibid 7.

${ }^{9}$ ibid 12.

10 'Im gorsze rządy, tym szara strefa większa' $<$ http://www.obserwatorfinansowy.pl/2011/12/24/szara-strefa-jakosc-rzadow $>2$, accessed 12.02.2012.

${ }^{11}$ Metodologia badań szarej strefy na rynku ustug (n 3) 13.
} 
Some of those who have already written about the grey area in the Polish economy claim that this kind of economic 'pathology' is possible due to the large share of cash in economic activity. They also claim that the grey area can be limited in Poland through increasing the role of electronic trading. One of the countermeasures in economic trading could be lowering sum limits, making it obligatory to transfer money ${ }^{12}$ and make payments in non-cash form. According to Friedrich Schneider, the scope of the grey area in Poland with reference to non-cash payment could have exceeded $30 \%$ of GDP in 2009. The calculated difference which shows the known income of entities that are economically 'active' is about 23 billion euro ${ }^{13}$.

\section{PROS AND CONS}

It is generally believed that the existence of the grey area is adverse because it causes many negative effects of a social and economic character ${ }^{14}$. Among negative effects of the grey area in the economy we can distinguish ${ }^{15}$ :

- falsification of economic statistics,

- understatement of tax inflows to the state budget,

- faulty "creation" of macroeconomic policy due to increasing cash turnover outside bank accounts,

- incorrect allocation of social assistance (family welfare),

- incorrect allocation of structural funds, in particular in the areas of education, training, investments in the data transmission and communications sector (ICT) ${ }^{16}$.

It is also highlighted that long-term avoidance of the law fosters destruction of social and economic life and creates pathologies. Falsified macroeconomic statistics concerning inflation in general result in the disinformation of economic authorities, and contributes to improper implementation of macroeconomic policy.

Here, as a complement to the negative impact of the grey area's functioning, we can mention illegal production conducted in legally functioning and registered companies; the primary and registered scope of their activity is only a 'smokescreen' for ${ }^{17}$ :

- illegal production,

- illegal employment,

- buying and selling without registration.

\footnotetext{
12 'Finansom publicznym na ratunek'

$<$ http://www.obserwatorfinansowy.pl/2010/11/04/finansom-publicznym-na-ratunek/> 3, accessed 12.02.2012.

${ }^{13}$ F Schneider, 'The Shadow Economy in Poland. How Payment System Help Limit the Shadow Economy' (Warsaw, 23 September 2009) A.T. Kearney, sponsored by VISA (2009), $<$ http://www.konferencje.kmbase.pl/downloads/ KrawczynskiEN.pdf $>$ 15, accessed 18.06.2012.

${ }^{14}$ Praca nierejestrowana w Polsce w 2010 r. (n 6) 15.

${ }^{15}$ K Piętka, 'Szara strefa jest w świetnej formie' Puls Biznesu (Warszawa, 12 March 2004).

${ }^{16}$ Metodologia badań szarej strefy na rynku ustug turystycznych (n 3) 14.

17 ibid 14
} 
However, economists also indicate advantages of the grey area in the economy, as it generates a positive influence on growth of the labour market, an increase in the number of so-called marginal places of work with low productivity and low remuneration which would not be created in the formal sphere of the economy. Additionally, it is also emphasised that those employed in the grey area, although they do not pay taxes directly, pay indirect taxes resulting from the purchase of products and services subject to VAT taxation. As a result, people who receive income from this area partially contribute to economic growth, increasing demand and registered employment ${ }^{18}$.

\section{INTERNET TRADE}

It follows from an analysis of the grey area conducted by Central Statistical Office that almost 42\% of GDP generated in the grey area in 2009 came from such sectors of economy as trade and services, and hotels and restaurants. This sphere of economic activity is a potential source of grey area income. Its presence significantly influences understatement of the effects of economic activity of registered companies and unregistered natural persons ${ }^{19}$. This results from the specific nature of performing activity in this area and from the particular way of contracting and regulating payments for transactions. Managing so-called e-trading is very often connected with trading of unregistered goods and services ${ }^{20}$. Enterprises managing activity via the Internet are subject to the same obligations as those present on the brick-and-mortar market. Managing business activity with the use of the Internet allows natural persons and other entities to avoid all the burdens imposed by tax law. This results from the fact that they provide incorrect identification data and telephone and address details on auctions, and the authorities that are supposed to enforce legal obligations are very often unable to identify the entities conducting transactions. Hiding or providing inaccurate personal and address data contributes to a great extent to the ineffectiveness of steps taken by law enforcement agencies to identify those committing fiscal offences ${ }^{21}$.

In studies of the sector, e-trading is described as the distance retail sale of consumer goods via the Internet ${ }^{22}$. Estimates of the value of e-trading in Poland 2009 conducted by the Direct Marketing Association fluctuate between 13-13.2 billion PLN. In studies on the sector, it is estimated that the sales volume on Allegro.pl alone amounted to 6 billion PLN ${ }^{23}$. However, observation of the Internet trading phenomenon in Poland allows us to state that it is growing dynamically, and the scale of legal activity is growing

\footnotetext{
18 ibid 15.

19 'Powiększa się szara strefa w Polsce' < http://news.time4men.pl/biznes/finanse/powiekszasie-szara-strefa-w-polsce>, accessed 12.02.2012.

20 'Informacja o funkcjonowaniu ,szarej strefy” w polskiej gospodarce i przeciwdziałania jej przez służby skarbowe’ (n 5) 7.

21 'Informacja o wynikach kontroli egzekwowania obowiązków podatkowych i celnych od podmiotów prowadzących handel internetowy', Najwyższa Izba Kontroli Delegatura w Kielcach (Kielce czerwiec 2010), 13.

22 'Badanie polskich sklepów internetowych i konsumentów' [2009] e - Handel Polska, 2.

23 ibid 6.
} 
together with a demand for these services. Additionally, a favourable circumstance is the popularization of electronic banking ${ }^{24}$.

The activity of entities on the Internet is of interest to organs responsible for enforcement of obligations. The Minister of Finance is responsible for supervision of actions conducted by authorities of tax, fiscal and customs control in the field of enforcing the tax and customs obligations of entities conducting Internet trading ${ }^{25}$. The object of their interest is trade and electronic or Internet services, and e-commerce (i.e. the process of concluding a contract for the sale and purchase of goods and services with the usage of electronic networks ${ }^{26}$.

In 2010 the Supreme Audit Office reported on a review held in the area of tax and customs obligations enforcement on entities conducting internet trading. In their evaluation, although in 2009 the Ministry of Finance intensified the system of activities to counteract irregularities in the Internet trading ${ }^{27}$, there were many irregularities pointed out which significantly influence effectiveness of the actions taken. The most important were ${ }^{28}$ :

- a lack of definition and understanding of the scale of Internet trade;

- a delay in the construction of a coherent system that indicates, identifies and monitors areas of risk where irregularities in the area of tax and customs obligations can be found;

- a lack of effective procedures and IT tools serving to indicate unregistered business activity and unreported taxable economic events, which should have been provided by the Ministry of Finance to subordinate authorities (fiscal, tax and customs);

- inadequate preparation of the authorities (fiscal, tax and customs) to conduct oversight of Internet trading, e.g. due to a lack of appropriate methodology.

Additionally, in the Supreme Audit Office report it was stated that there is no coherent system for collecting and processing information in this area, and also that no tools were implemented to facilitate the work of fiscal, tax and customs authorities that monitor electronic networks and indicate entities that should be inspected ${ }^{29}$.

In the works of the Supreme Audit Office they place emphasis on effectiveness and adequacy of choosing the entities to be audited, which should be supported by an analysis conducted before undertaking inspection procedures. This analysis would make it possible to indicate entities from the highest risk group, those potentially creating and expanding the grey area. According to the Supreme Audit Office it is necessary to create IT tools to regulate the areas of Internet trade that should get more specialised attention. Due to the complexity and scale of grey area phenomena, it is very often emphasized that the most effective and efficient tools for eliminating it are changes to legislative acts.

\footnotetext{
24 'Informacja o funkcjonowaniu „szarej strefy” w polskiej gospodarce i przeciwdziałania jej przez służby skarbowe' (n 5) 7.

25 'Informacja o wynikach kontroli egzekwowania obowiązków podatkowych i celnych od podmiotów prowadzących handel internetowy' (n 21) 7.

26 ibid 4.

27 ibid 7.

28 ibid 7.

29 ibid 8 .
} 
They should enable:

- elimination of such legal solutions that are at present conducive to the functioning of the grey area,

- implementation of such legal instruments which enable and encourage the registration of commercial activity ${ }^{30}$.

\section{CONCLUSIONS}

The conclusions in this study are that the grey area is a common phenomenon independent of the type of economy considered, and come from the experience of other countries that have fought against the grey area. It was explicitly stated that grey area phenomena can be only limited, but not eliminated. What should be highlighted is the fact that all the actions taken in order to counteract the grey area should be thoughtfully planned, and should include areas as legislation, social and economic policies of a given country, and all the actions by authorities that are specially created to fight against pathologies in economic trading. Therefore, all potential solutions should include ${ }^{31}$ :

1. a sphere of legislative solutions:

- creating coherent, precise and stable legislative frameworks that regulate the way business activity is managed, in particular financial and tax regulations;

- stimulating economic activity by citizens, for instance by lowering the costs of creating new workplaces;

- simplifying tax regulations, reviewing and verifying existing exemptions, liquidating reliefs, introducing equality of entities under the law, limiting fiscality;

2. a sphere of procedural solutions regarding authorities that are obliged to enforce tax and customs obligations:

- developing field strategies to restrict the grey area taking into account the specificity of particular branches of the economy and professions;

- creating effective mechanisms of audit, prosecution and punishment of entities acting in the grey area, including improvement in the forms of work of fiscal and customs services;

- self-analysis of available information from different organs, including those gathered by specialised services, information coming from mass media, signals given by entrepreneurs and their organizations, and citizens.

3. a sphere of social awareness improvement:

- education of society that is supposed to inform about the close dependence between payments due to the state and the state's obligations in the areas of ensuring health care, accurate functioning of the judiciary, public security, and the fact that those who suffer from the existence of the grey area are not only the state but also all its citizens - and in particular honest taxpayers.

\footnotetext{
30 'Informacja o funkcjonowaniu ,szarej strefy” w polskiej gospodarce i przeciwdziałania jej przez służby skarbowe' (n 5) 12.

${ }^{31}$ ibid 13 .
} 
Limiting or fighting against the grey area in the Internet should be thoroughly planned and should be comprehensive. It would be advisable to cover all the possible areas of social and economic life in which it exists. Inaction leads to the multiplication of unfavourable phenomena and even pathologies, and as a consequence the negative effects damage the whole society.

Therefore, it is vital to act in a comprehensive (systematic) way in a range of areas. The most important thing is to monitor and supervise the proper functioning of institutions responsible for limiting or eliminating the grey area. Additionally, liberalization of regulations and the application of various 'reliefs' for legally-operating economic entities should help other entities exit the grey area. 